\title{
Use of cable bolts to reinforce the hanging pillars and improve the ore recovery when stopes are mined using double top sills at Vale's Copper Cliff Mine
}

\author{
DR Chinnasane Vale Canada Ltd., Canada \\ M Knutson Vale Canada Ltd., Canada \\ A Watt Vale Canada Ltd., Canada
}

\begin{abstract}
There is variability in the geometry of the ore outline, particularly between the footwall (FW) and hanging wall (HW), across the strike length of the various orebodies at Copper Cliff Mine. This geometry creates a requirement to plan transverse sills on one side of the orebody and longitudinal sills on the other side of the orebody on certain levels. In fact, there have been instances where some stopes have been mined using two sills (either transverse or longitudinal) on the top cut. With Vale's Vertical Retreat Mining Method (VRM), the drilling must be done from both of the top sills using an in-the-hole (ITH) drill. Once the crown part of the stope has been blasted, an undercut pillar or hanging pillar, i.e. a pillar without any support beneath it, is created. Without any additional reinforcement installed into the hanging pillar, there is a high probability that the hanging pillar itself will fail simply by falling into the open stope as a result of the lack of confinement. The sudden failure of a hanging pillar can lead to additional instability as a result of the excessive span across the open stope. The failed material can also lead to operational issues such as a choked drawpoint; in this case, large pieces of ore inhibit mucking in the bottom sill, thus making it difficult to recover all the ore from the stope.
\end{abstract}

Cable bolts have been proven to be one of the most effective reinforcing ground support elements for different applications in underground hard rock mining. Specifically at Copper Cliff Mine, cable bolts are used to pre-support the pillars between the top sills, prior to crown blasting and prior to creating the hanging pillar geometry. Later in the mining cycle, the hanging pillars are further supported by backfill; the fill is placed tight underneath the hanging pillars for long-term, regional support. To date, 10 stopes have been successfully mined in various orebodies at Copper Cliff Mine using cable bolts to support hanging pillars during mining.

This paper describes case studies where pillars were undercut, and includes an outline of the methods that were used to mitigate the risks of ground failure. A discussion of the cable bolt design methodology for hanging pillar geometries, and a summary of the benefits achieved in terms of safety, stability and additional ore recovery as also included.

\section{$1 \quad$ Introduction}

Copper Cliff Mine is located within the Copper Cliff Offset in the limits of the City of Greater Sudbury, Ontario, Canada, as shown in Figure 1. The Copper Cliff Offset extends about $8 \mathrm{~km}$ south from the Sudbury Igneous Complex into the FW rocks. Until 2008, the current Copper Cliff Mine was operated as two separate mines, i.e. North Mine and South Mine. However, as part of restructuring of Vale Ontario Operations, the North and South Mines were merged in 2009 to form the Copper Cliff Mine. 


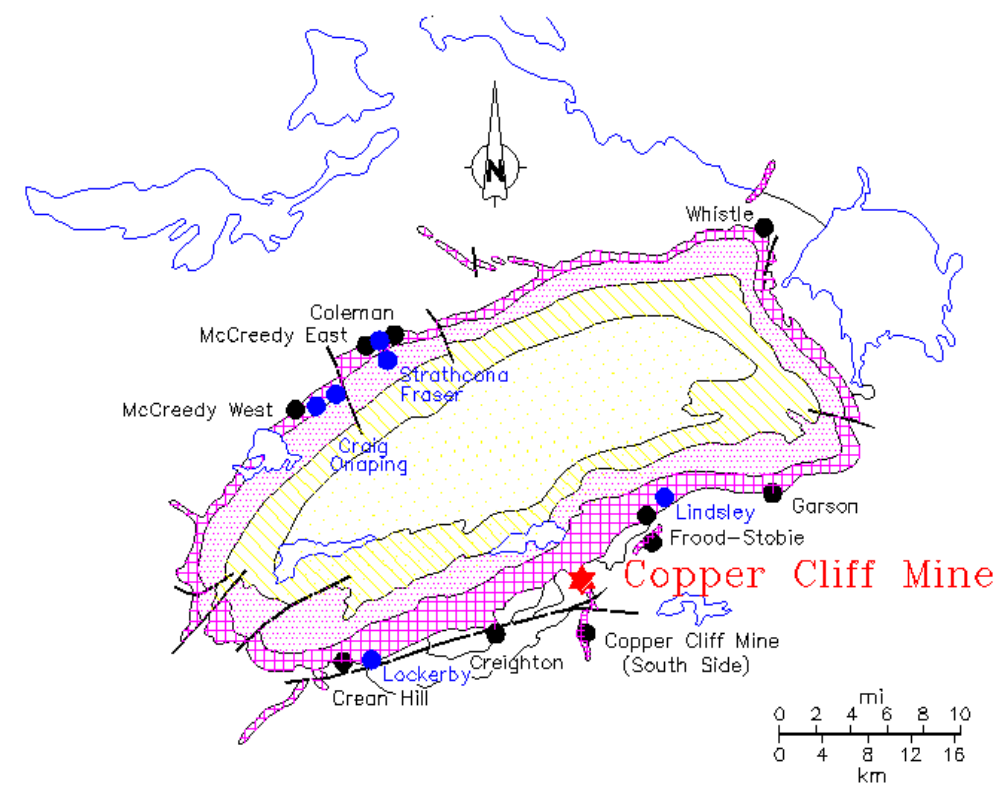

Figure 1 Location of Copper Cliff Mine in the Sudbury Basin of Vale Operations

\section{$2 \quad$ Orebodies}

There are about fourteen major orebodies present at the Copper Cliff Mine. Different orebodies along with major geological structures (blue dashed lines) are shown in Figure 2. Out of all the orebodies, currently the ore is being produced mainly from the $880,865 / 860,100 / 900,790 / 800 / 810$ and 830 orebodies at the Copper Cliff Mine.

\section{Longitudinal Section: Copper Cliff Mine Ore Bodies}

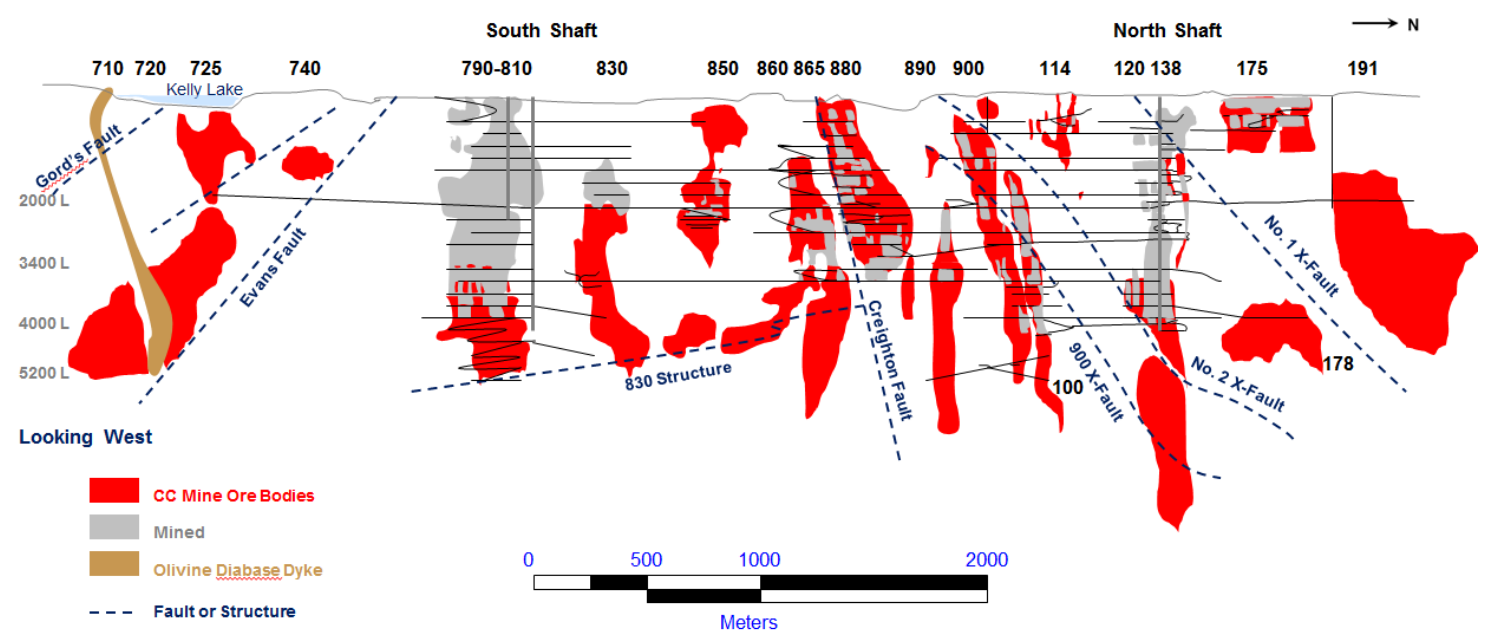

Figure 2 Long section showing different orebodies and the major geological structures at the Copper Cliff Mine

\section{Problems with variability in the orebody geometry}

The geometry of the ore outline varies particularly between the FW and HW across the strike length of the various orebodies at Copper Cliff Mine. The variability in the geometry of the orebodies often poses some planning difficulties to completely recover the ore, particularly from the area of the stope where the orebody is much wider compared to adjacent stopes where the orebody is narrower on the same level. The variation in the orebody geometry creates a requirement to plan for two sills on one side of the orebody (either transverse or longitudinal) and a single sill on the other side of the orebody on the same horizon. 
For instance, in the 880 orebody as per the original ore wireframe the width of the orebody on $2660 \mathrm{~L}$ was narrow but wider on 2800L. In view of this reason, it was planned to develop a longitudinal sill on 2660L and transverse sills on $2800 \mathrm{~L}$ to mine the stopes between $2660 \mathrm{~L}$ and $2800 \mathrm{~L}$. Accordingly, a longitudinal sill was developed on $2660 \mathrm{~L}$ and various transverse sills were developed on $2800 \mathrm{~L}$.

However, while mining the stopes between $2660 \mathrm{~L}$ and $2800 \mathrm{~L}$, there were some indications of the orebody getting wider than originally thought along the strike length of the orebody on 2660L. The Mines Technical Services department (sngineering and geology) investigated this further by drilling some test holes and probed them. Probing the test holes confirmed the additional ore on the HW side of the 275 sill drift in the 1001 and 951 stope boundaries on 2660L. This change in the ore outline necessitated the mine planners to plan for another longitudinal sill (i.e. 250 sill) driving parallel to the previously developed sill (i.e. 275 sill) on 2660L. Without this second sill, it would not be possible to effectively drill the 1001 and 951 stopes and extract the entire width of the orebody. Figure 3 shows how the variability in the orebody geometry on $2660 \mathrm{~L}$ necessitated the mine planners to plan for two sills on the top cut in order to maximise the ore extraction from the 1001 and 951 stopes between $2660 \mathrm{~L}$ and $2800 \mathrm{~L}$.

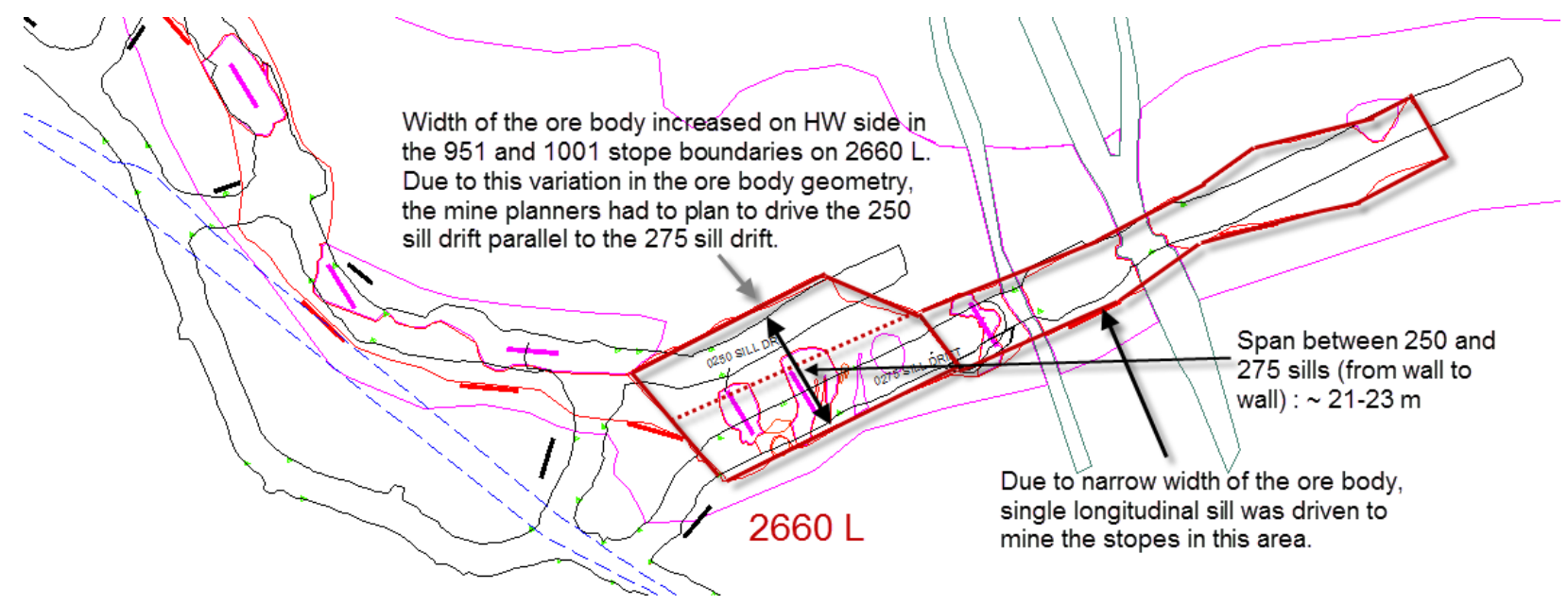

Figure 3 Plan view showing the layout of two top sills to properly mine the 1001 and 951 stopes between 2660 and $2800 \mathrm{~L}$ in the 880 orebody

Figure 3 shows the span from wall to wall including the pillar between the 250 and 275 sills (width of the pillar is approximately $10.5 \mathrm{~m}$ ) in the 1001 and 951 stope areas the span ranges from $21-23 \mathrm{~m}$. In order to mine these stopes using VRM, the drilling must be done from both of the top sills using an ITH drill. Once the crown of the stope has been blasted, it will create an undercut pillar or hanging pillar (i.e. a pillar without any support beneath it). Without any additional reinforcement installed into the hanging pillar, there is a high probability that the hanging pillar itself will fail simply by falling into the open stope as a result of the lack of confinement. The sudden and complete failure of a hanging pillar can lead to additional instability as a result of the increased span (in this case approximately 21-23 m) across the open stope. The failed material can also lead to operational issues such as a choked drawpoint; in this case, large pieces of ore inhibit mucking in the bottom sill thus making it difficult to recover all the ore from the stope. A typical section view of the pillar that will be undercut after the crown of the stope has been blasted in the 1001 and 951 stopes between 2660L and 2800L is shown in Figure 4. 


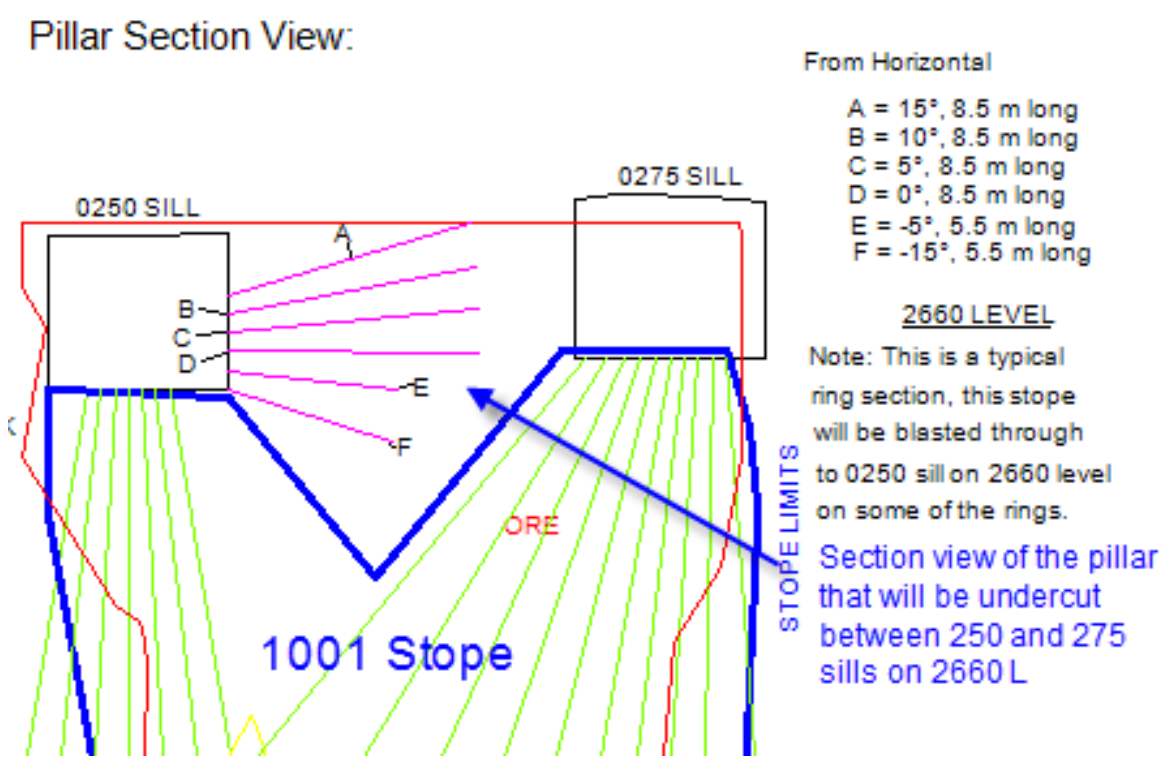

Figure 4 Typical section view showing the pillar that will be undercut once the crown of the stope has been blasted on $266 \mathrm{oL}$ in the 880 orebody

\section{$4 \quad$ Why cable bolts?}

Cable bolts have been proven to be one of the most effective reinforcing ground support elements for different applications in underground hard rock mining. Hutchinson and Diederichs (1996) provided an overview of how and where the cable bolts can be used to support, reinforce or retain the rock mass around most excavations in an underground mine, including:

- Drifts and intersections.

- Open stope backs.

- Cut-and-fill stopes (not applicable for Copper Cliff Mine).

- Draw points.

- Permanent openings such as garages, storages and crusher stations.

At the Copper Cliff Mine, in addition to most of the above applications, cable bolts are also used to pre-support the pillars between the top sills, prior to crown blasting and creating the hanging pillar geometry. The purpose of the cable bolting is mainly to reinforce the pillar that will be undercut and ensure that the undercut pillar will remain stable until the stope has been backfilled. At the Copper Cliff Mine, there have been quite a few instances where stopes had to be mined using two sills (either transverse or longitudinal) and where the pillars between the two sills had to be cable bolted in order to maintain the stability of such hanging pillars. To date, 10 stopes have been mined successfully in different orebodies. The list of the stopes that have been successfully mined using cable bolts as reinforcement elements to support the hanging pillars between two sills at the Copper Cliff Mine are given in Table 1. 
Table 1 List of the stopes that have been successfully mined in the past using two sills at the Copper Cliff Mine

\begin{tabular}{|c|c|c|c|}
\hline Name of the stope & Orebody & Sill type on top cut and level & Sill type on bottom cut and level \\
\hline 1001 & 880 & Longitudinal - 2660L & Transverse $-2800 \mathrm{~L}$ \\
\hline 951 & 880 & Longitudinal $-2660 \mathrm{~L}$ & Transverse $-2800 \mathrm{~L}$ \\
\hline 1301 & 865 & Longitudinal - $2750 \mathrm{~L}$ & Longitudinal - $2890 \mathrm{~L}$ \\
\hline 1251 & 865 & Longitudinal $-2750 \mathrm{~L}$ & Longitudinal $-2890 \mathrm{~L}$ \\
\hline 2651 & 865 & Transverse $-3350 \mathrm{~L}$ & Transverse $-3500 \mathrm{~L}$ \\
\hline 291 & 880 & Transverse $-2270 \mathrm{~L}$ & Transverse $-2490 \mathrm{~L}$ \\
\hline 9451 & 830 & Transverse $-3200 \mathrm{~L}$ & Transverse $-3400 \mathrm{~L}$ \\
\hline 9510 & 100 & Transverse $-3880 \mathrm{~L}$ & Transverse $-4050 \mathrm{~L}$ \\
\hline 2831 & 900 & Longitudinal $-2000 \mathrm{~L}$ & Longitudinal $-2150 \mathrm{~L}$ \\
\hline 2781 & 900 & Longitudinal $-2000 \mathrm{~L}$ & Longitudinal - $2150 \mathrm{~L}$ \\
\hline
\end{tabular}

\section{$5 \quad$ Cable bolt design considerations and methodology}

The key considerations involved in the design of cable bolts in the underground mine environment are given in Figure 5 (Hutchinson \& Diederichs 1996).

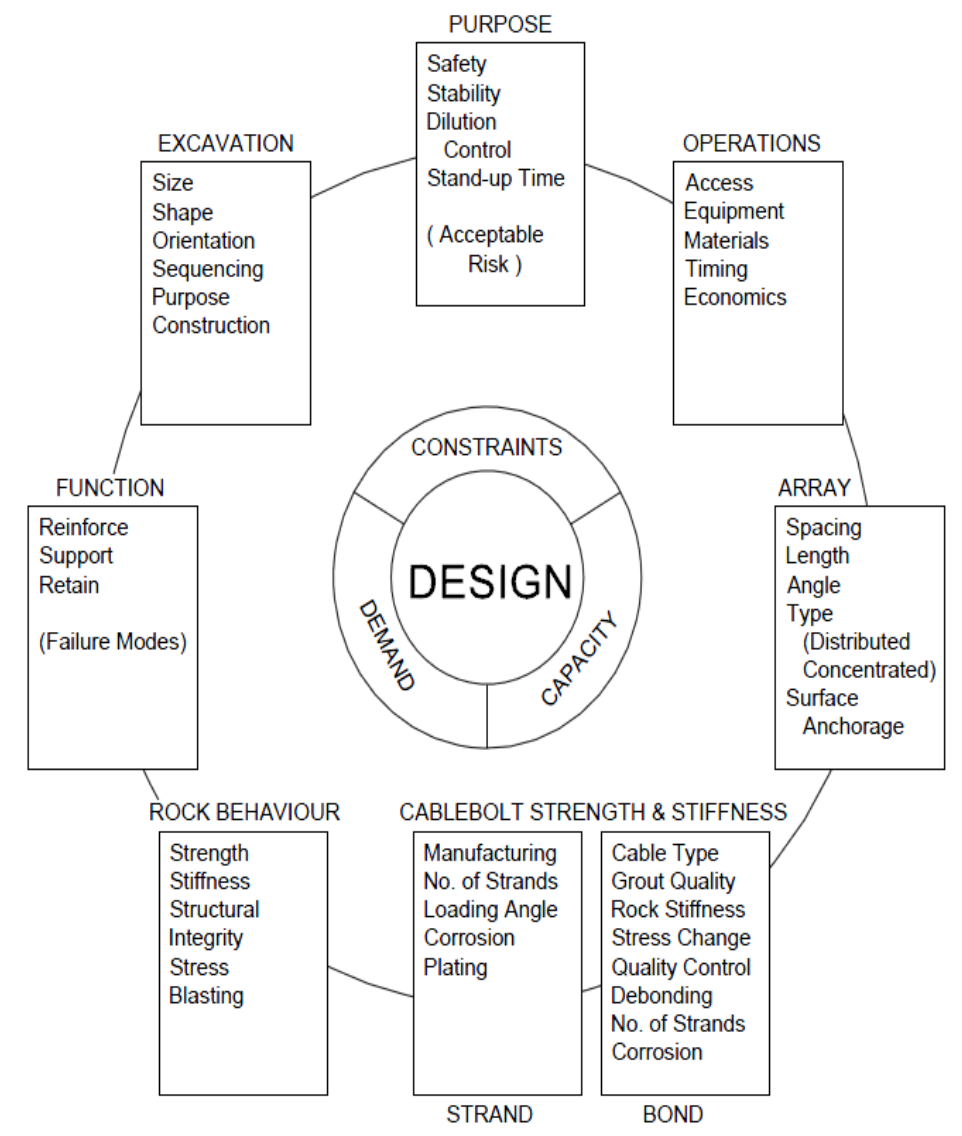

Figure 5 Key considerations for cable bolt design in underground mines (Hutchinson \& Diederichs 1996) 
All the design considerations that were adopted in the design of cable bolts are not discussed in detail as they fall beyond the scope of this paper. However, the main aspects that were considered and methodology that was used in designing the cable bolts are presented below:

- Demand (calculate the dead weight of the hanging pillar that need to be supported).

- Capacity (determine the length, spacing, type and number of cable bolts).

- Purpose and service life (to ensure the stability of hanging pillar until the stope is backfilled).

- Factor of Safety (FS). lin view of the short service life, the design was based on FS of 1.3-1.5.

Though the blast vibrations (particularly the crown blast) and induced stresses could impact the stability of the hanging pillar to some extent, these factors were not taken into account in the design of the cable bolts for hanging pillars. The design methodology to reinforce the hanging pillar between 250 and 275 sills on 2660 L (Figure 6) in the 880 orebody is demonstrated in Table 2 below.

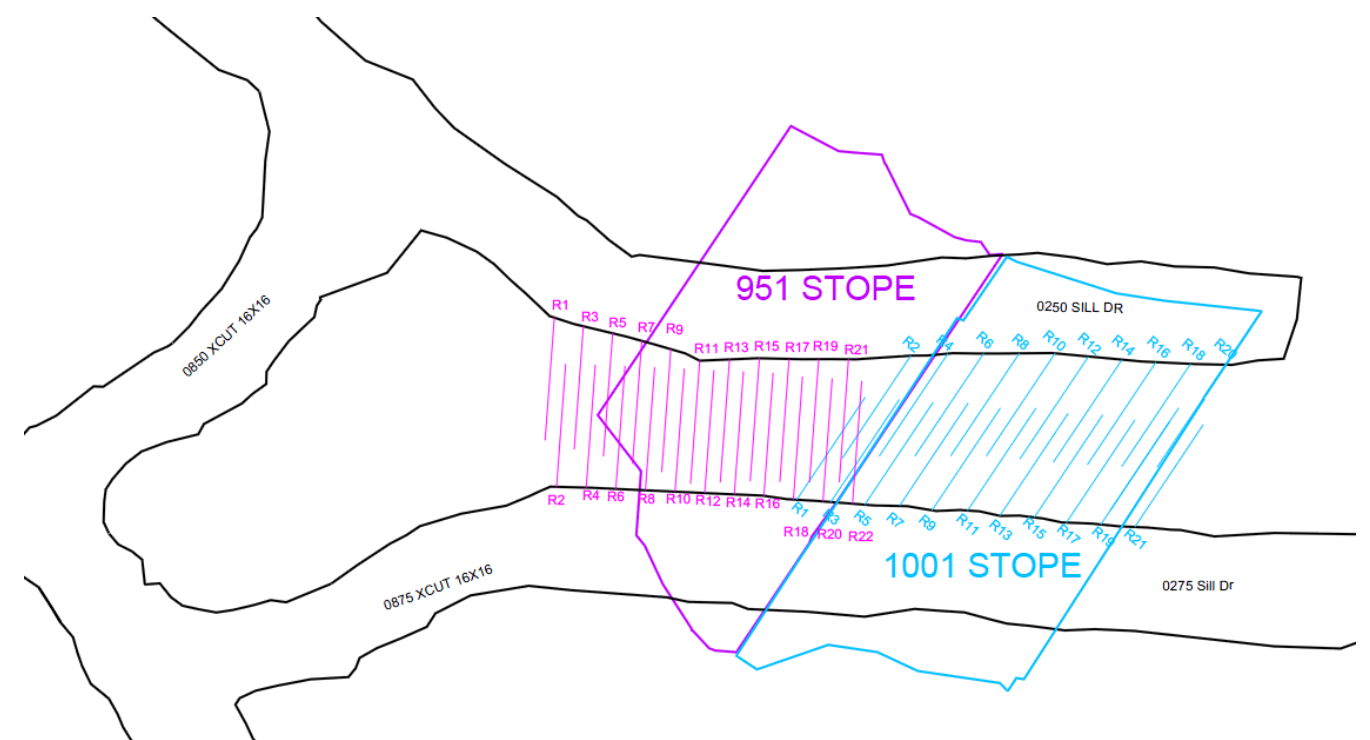

Figure 6 Plan view showing layout of cable bolts (staggered) into the pillar between 250 and 275 sills on 266 oL

Table 2 Outlining the steps in cable bolt design methodology to reinforce the hanging pillar between 250 and 275 sills on $2660 \mathrm{~L}$

\begin{tabular}{cc}
\hline Width of the pillar between 250 and 275 sills & $10.5 \mathrm{~m}$ \\
Length of the pillar that will be undercut between 250 and 275 sills & $44.2 \mathrm{~m}$ \\
Height of the pillar that needs to be reinforced & $6.1 \mathrm{~m}$ \\
Volume of the pillar to be supported (width $\times$ length $\times$ height) & $2,833 \mathrm{~m}^{3}$ \\
Dead weight of the hanging pillar (volume $\times$ density) at $30 \mathrm{kN} / \mathrm{m}^{3}$ & $85,000 \mathrm{kN}$ \\
Capacity of one twin cable bolt (one-plain and one-bulbed) & $500 \mathrm{kN}$ \\
Number of cable bolts required (Dead weight $\div$ cable bolt capacity) & 170 \\
For FS of 1.5, the minimum cable bolts required will be & 255 \\
Number of rings required to cover the entire pillar length (at 1.8 m spacing) & 43 \\
(21 rings on 250 sill side and 22 rings on 275 sill side on staggered pattern) & 6 \\
Number of cable bolts per ring section (255 $\div$ 43 = 5.9) & \\
\hline
\end{tabular}


Figure 6 shows the cable bolt rings are spaced every $1.8 \mathrm{~m}$ on both sides, but the rings are staggered with respect to each other on 250 and 275 sills. The reason for choosing this kind of pattern is mainly to reduce the effective spacing between the rings in the core part of the pillar to $0.9 \mathrm{~m}$. By reducing the effective spacing between cable bolt rings inside the pillar, the stiffness is increased in the pillar. Further, the reduced spacing helps to hold blocks together and make the reinforced pillar act as beam, which not only can support itself, but also take some additional load induced by the crown blast. A typical section view of the cable bolts within a ring in the 1001 stope is shown in Figure 7.

The length of the cable bolts was mainly determined based on the width of the pillar that needs to be supported. Based on the pillar geometry between 250 and 275 sills, $8.5 \mathrm{~m}$ long cable bolts (A, B, C and D) were used in the upper part of the pillar and in the lower part of the pillar, $5.5 \mathrm{~m}$ long cable bolts were used. The rationale behind the use of two different lengths of cable bolts was mainly to maximise the cable bolt coverage in the upper part of the pillar and at the same time minimise the risk of ITH holes intersecting with the installed cable bolts in lower part of the pillar.

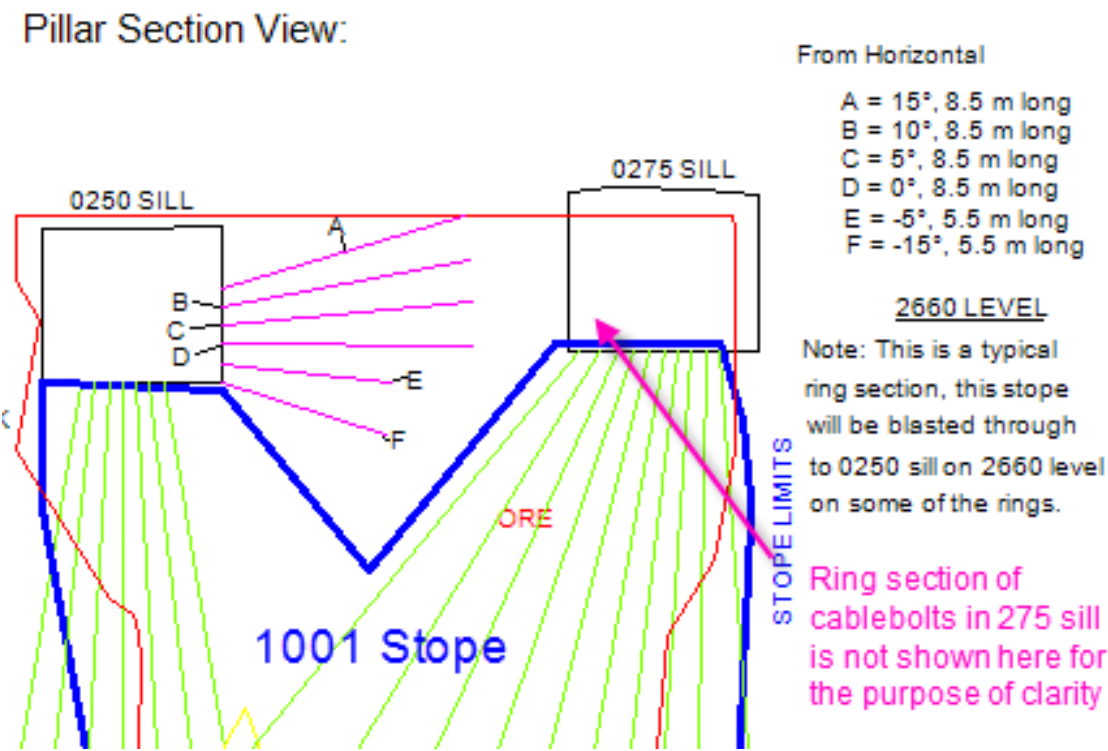

Figure 7 Section view showing the pillar to be reinforced between 250 and 275 sills on $2660 \mathrm{~L}$

\section{Effectiveness of cable bolts in stabilising the hanging pillars}

Based on field observations and the cavity monitoring survey (CMS) results, the cable bolts have been proven to be very effective in stabilising the hanging pillars in different orebodies at the Copper Cliff Mine. However, it was observed in some cases that the lower part of the pillar (the triangle shaped wedge) may simply drop or fail into the open stope either concurrently with the crown blast or during the mucking cycle. The reason for ineffectiveness of cable bolts in the lower part of the pillar could be due to combination of many factors such as high vibration caused by the crown blast, lack of confinement from underneath the pillar and the associated stress changes due to low confinement. In fact, research has shown (Kaiser et al. 1992; Hyett et al. 1993) that stress change in the surrounding rock mass after the installation of cable bolts can profoundly affect the bond strength of the cable bolts. In short, stress increases increase the bond strength while stress decreases can reduce the bond strength (Hutchison \& Diederichs 1993). Once the crown is blasted, it is obvious that the natural confinement supporting the pillar is no longer available. In view of this low confinement region in the lower part of the pillar, it is likely that bond strength of the cable bolts could have been reduced leading to failure of the cable bolts. Even though, the lower part of the pillar experienced some failure in some cases, the overall stability of the hanging pillars could be maintained until the backfill is placed tight against the undercut pillar in all the cases. 
Figure 8 shows the cable bolts that were installed to reinforce the pillar between 250 and 275 sills in the 951 stope and 1001 stope areas on 2660L in the 880 orebody. The lower block in Figure 8 shows the effectiveness of cable bolts in stabilising the hanging pillar once the crown was blasted in the 1001 stope. Note that even though there was some superficial damage in the lower part of the pillar in certain sections, overall the undercut pillar remained stable from the time the crown was blasted (9 April 2013) to until such time the stope was tight filled (28 August 2013).

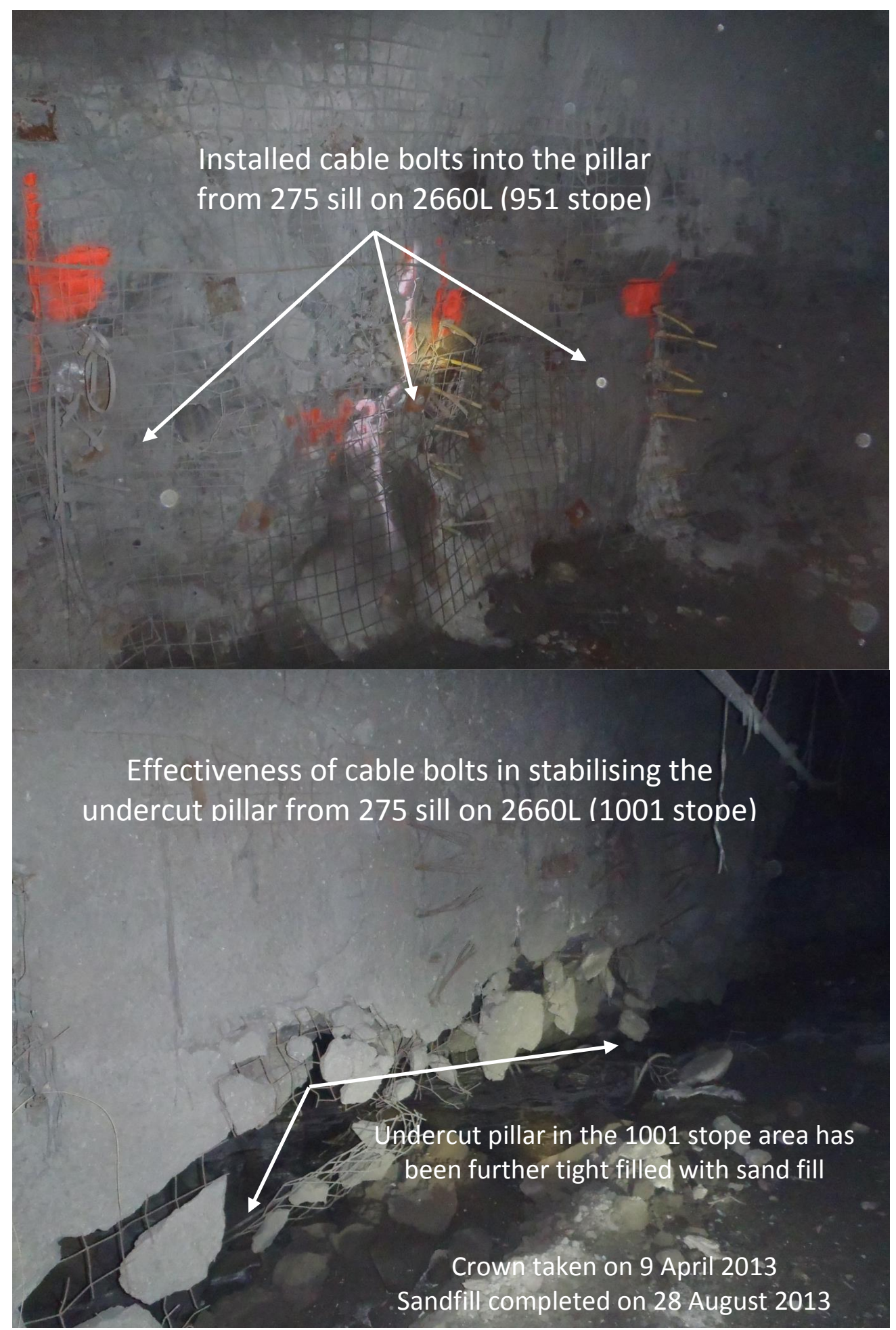

Figure 8 Cable bolts that installed to reinforce the pillar between 250 and 275 sills on $2660 \mathrm{~L}$ 
The effectiveness of cable bolts in the 951 stope area can be seen in Figure 9. CMS results clearly shows that the pillar, which was reinforced with cable bolts, remains stable after the crown was blasted on 13 March 2014. As this stope is currently being filled, the undercut pillar will be tight filled to achieve the long-term stability of the hanging pillar.

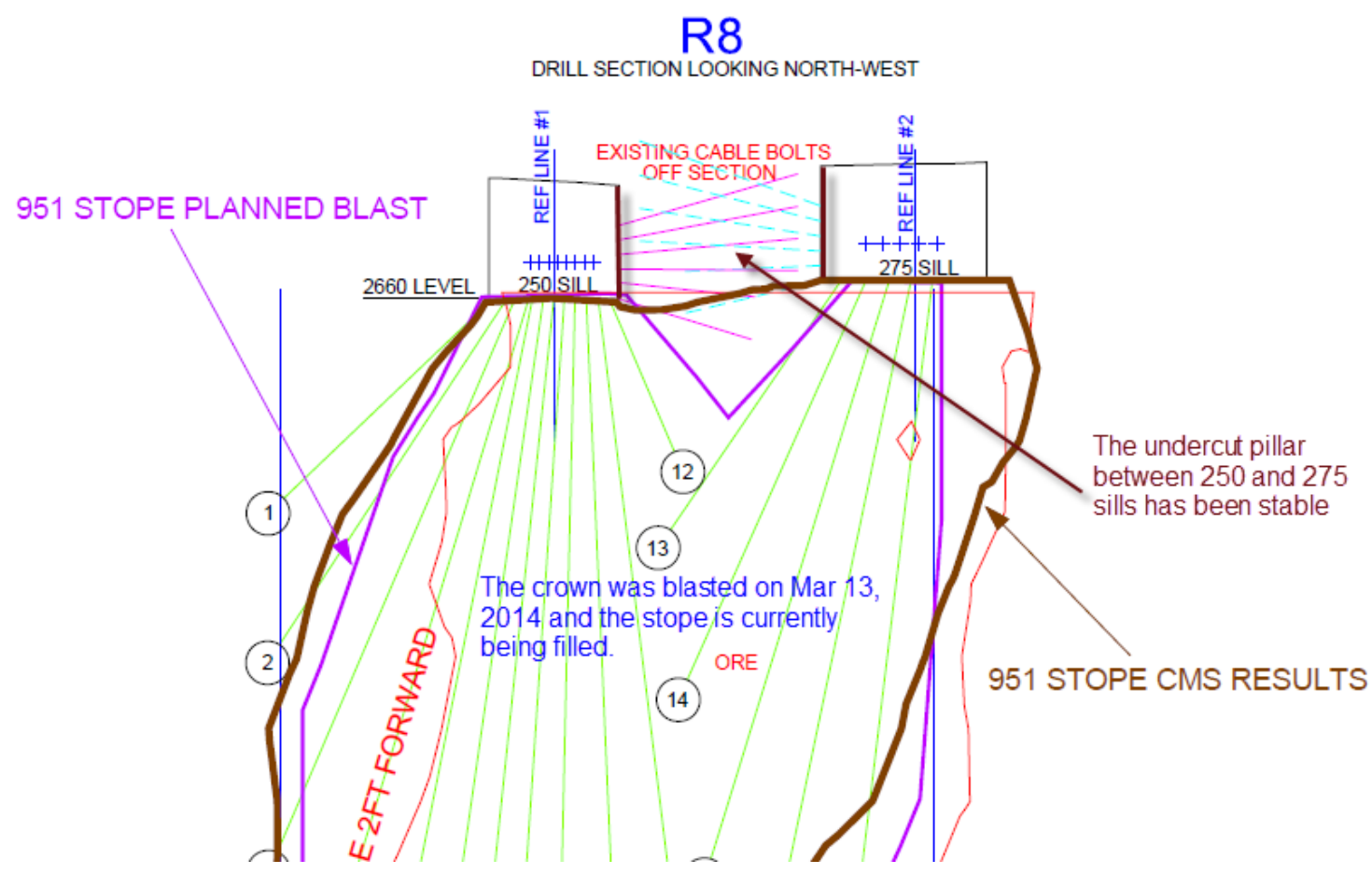

Figure 9 Section view showing the stable pillar between 250 and 275 sills in the 951 stope area on 266 oL

\section{Benefits achieved in terms of safety, stability and additional ore recovery}

Based on the examples presented, there are obvious benefits to using cable bolts as reinforcing elements in the stopes that will be mined using two sills in the top cut. In addition to the safety and stability of the work places, cable bolting of the hanging pillars enable the mine planners to layout the stope such that ITH holes can be drilled from two sills in order to properly drill off the stope and maximise the ore recovery. The amount of additional ore recovery and the value of such additional ore recovery from the recently mined out stopes at the Copper Cliff Mine are given in Table 3.

Without cable bolting, stability of the hanging pillar cannot be maintained due to increased span across the open stope. If the stability of the undercut pillar cannot be maintained then it could lead to further unravelling taking the failure above the back elevation of the stope that is being mined. Such failures could lead to regional instability, which could in turn pose serious safety concerns to the operations. So, the use of cable bolts not only helps in improving the safety and stability of the personnel and work places but also helps in maximising the ore recovery in the stopes where additional ore is available. It should be noted the additional cost incurred for cable bolting is negligible compared to the net benefit that is gained by the additional ore recovery.

For instance, due to variation in the orebody geometry in the 951 and 1001 stope areas, it was planned to develop a second sill, the 250 sill parallel to the previously developed 275 sill on $2660 \mathrm{~L}$. The length of the proposed additional development was approximately $50 \mathrm{~m}$ and it cost approximately CAD 300,000 (at CAD 6,000 per metre of drift development). The cost of cable bolting is calculated to be around CAD 120,000 (at CAD 49 per metre of cable bolting including material and labour). So, the total additional cost comes to about CAD 420,000. As shown in Table 3, the additional ore that was recovered from the 951 and 1001 stopes was 11,600 t. So, the cost that was incurred for recovering the additional ore was only about CAD 36 per $t$ for the part of additional ore gained. 
Table 3 Value of additional ore gained from the recently mined stopes at the Copper Cliff Mine

\begin{tabular}{|c|c|c|c|c|}
\hline Name of the stope & Orebody & $\begin{array}{l}\text { Additional } \\
\text { ore gained } \\
\text { (t) }\end{array}$ & $\begin{array}{c}\text { Value of the gained } \\
\text { ore (CAD) }\end{array}$ & Comments \\
\hline $\begin{array}{c}1001 \\
(2660 \mathrm{~L}-2800 \mathrm{~L})\end{array}$ & 880 & 5,250 & $\begin{array}{c}0.8 \text { million } \\
\text { (CAD } 150 \text { per } \mathrm{t})\end{array}$ & $\begin{array}{l}\text { Approximately } 50 \text { m of } \\
\text { additional development } \\
\text { was required for both } 951 \\
\text { and } 1001 \text { stopes }\end{array}$ \\
\hline $\begin{array}{c}951 \\
(2660 L-2800 L)\end{array}$ & 880 & 6,350 & $\begin{array}{c}1.1 \text { million } \\
\text { (CAD } 175 \text { per } \mathrm{t})\end{array}$ & \\
\hline $\begin{array}{c}1301 \\
(2750 L-2890 L)\end{array}$ & 865 & 12,650 & $\begin{array}{c}2.5 \text { million } \\
\text { (CAD } 204 \text { per } \mathrm{t} \text { ) }\end{array}$ & \\
\hline $\begin{array}{c}2651 \\
(3350 L-3500 L)\end{array}$ & 865 & 8,200 & $\begin{array}{c}2 \text { million } \\
\text { (CAD } 249 \text { per } \mathrm{t} \text { ) }\end{array}$ & \\
\hline $\begin{array}{c}291 \\
\text { (2270L-2490L) }\end{array}$ & 880 & 15,000 & $\begin{array}{c}4.8 \text { million } \\
\text { (CAD } 323 \text { per } t)\end{array}$ & \\
\hline \multirow[t]{2}{*}{$\begin{array}{c}9451 \\
(3200 L-3400 L)\end{array}$} & 830 & 9,645 & $\begin{array}{c}1.6 \text { million } \\
\text { (CAD } 170 \text { per } \mathrm{t} \text { ) }\end{array}$ & \\
\hline & Total & 57,095 & $12.8 \mathrm{~m}$ & \\
\hline
\end{tabular}

\section{Conclusions}

The cable bolts were proven to be very effective in maintaining the overall stability of the hanging pillars and thereby improving the safety of the underground mining operations when stopes were mined using two sills. To date, 10 stopes have been successfully mined in various orebodies at Copper Cliff Mine using cable bolts to support the hanging pillars during mining. Without employing the cable bolts as reinforcing elements, it wouldn't have been possible to maximise the ore recovery from the stopes where the additional ore was available due to local variations in the orebody geometry.

\section{Acknowledgements}

The authors express their thanks to Steve Runnalls, Manager - Mines Technical Services and Samantha Espley, General Manager - Mines Technical Services for granting the permission to publish this paper. Also, encouragement received from Tim Verlaan, Chief Mine Engineer, Copper Cliff Mine, Mike Yao, Principal Ground Control Engineer (Central Support) and Bob MacDonald, Mine Manager, Copper Cliff Mine is greatly appreciated.

\section{References}

Hutchinson, J \& Diederichs, M 1993 'An Instrumentation Program for Performance Monitoring of a Cable Bolt Reinforced Rock Mass', in T Szwedzicki (ed.), Geotechnical Instrumentation and Monitoring in Open Pit and Underground Mining, A.A. Balkema, Rotterdam, pp. 237-244.

Hutchinson, J \& Diederichs, M 1996, Cablebolting in Underground Hard Rock Mines, a practical guide and final report of a joint research project through Mining Research Directorate, Canada and Australian Mineral Industries Research Association, viewed 9 August 2014, http://geol.queensu.ca/people/mdiederi/cablebolting_in_underground_mines.pdf

Hyett, AJ, Bawden, WF \& Reichert, RD 1993, 'The effect of rock mass confinement on the bond strength of the fully grouted cable bolts', International Journal of Rock Mechanics Mining Sciences \& Geomechanics Abstracts, vol. 29, no. 5, pp. 503-524.

Kaiser, PK, Yazici, S \& Nose, J 1992, 'Effect of stress change on the bond strength of fully grouted cables', International Journal of Rock Mechanics Mining Sciences \& Geomechanics Abstracts, vol. 29, no. 3, pp. 293-306. 